\title{
Numerical Taxonomy of Haemophilus and Related Bacteria
}

\author{
P. H. A. SNEATH and R. JOHNSON \\ Medical Research Council Microbial Systematics Unit, University of Leicester, Leicester, England, and \\ Computer Trials Laboratory, Central Public Health Laboratory, Colindale, London NW9, England
}

\begin{abstract}
A numerical taxonomic study of named strains of Haemophilus Winslow et al., Actinobacillus Brumpt, and Pasteurella Trevisan was made using 134 characters covering a wide range of properties. The strains fell into four main clusters. Three of these represented Haemophilus. Cluster 1 contained strains requiring $\mathrm{X}$ factor and usually also $\mathrm{V}$ factor and corresponded to $H$. influenzae (Lehmann and Neumann) Winslow et al. and closely allied organisms. Cluster 2 contained strains that required only $\mathrm{V}$ factor and corresponded to $H$. parainfluenza Rivers and similar organisms. Cluster 3 contained strains with a requirement for a raised $\mathrm{CO}_{2}$ tension and contained $H$. aphrophilus Khairat and $H$. paraphrophilus Zinnemann. Cluster 4 contained strains of Actinobacillus and Pasteurella but not Yersinia van Loghem. The three genera Actinobacillus, Pasteurella, and Haemophilus have a close phenetic relationship and are facultative anaerobes that can acidify glucose fermentatively. They might best be separated from the other genera of the family Brucellaceae Breed et al.
\end{abstract}

The genus Haemophilus Winslow et al. 1917, although of considerable medical importance, has received relatively little detailed study, as shown by the paucity of comparative data in works such as the 7th edition of Bergey's Manual (7). Some species once included in the genus have been segregated as a separate genus, Bordetella; the remainder have been studied mainly with respect to rather few properties, notably growth requirements and hemolysis. The taxonomic structure within the genus, and its relation to other genera, is uncertain, and we therefore present this brief report in the hope that it will stimulate further comparative work on the group.

The 7th edition of Bergey's Manual contains 15 species of Haemophilus. Several of these $(H$. citreus, $H$. influenzae-murium, $H$. ovis, and $H$. putoriorum) are very poorly known, and authentic strains do not appear to be available, although attempts are being made to reisolate some of them (4). Certain other species assigned to Haemophilus were noted in an earlier edition of Bergey's Manual (6) or in Index Bergeyana (8) under Haemophilus or Hemophilus; these are even more poorly known and include $H$. anatipestifer, $H$. cuniculi, $H$. meningitidis, and $H$. muris. Species described more recently include $H$. paraphrophilus Zinnemann et al. 1968 and $H$. paraphrohaemolyticus
Zinnemann et al. 1971, which are similar in many ways to $H$. aphrophilus Khairat 1940. $H$. agni Kennedy et al. 1958, which causes a septicaemia of lambs, also appears to resemble H. aphrophilus, and similar organisms have been isolated from meningoencephalitis of cattle $(25$, 46).

Haemophilus pleuropneumoniae Shope 1963, a very pleomorphic, V-requiring organism causing pleuropneumonia of swine, is similar to the strains of influenza bacilli from swine that require V factor only (47), and thus it is probably similar to $H$. parainfluenzae and to the recently described species $H$. paragallinarum Biberstein and White 1969 and $H$. parasuis Biberstein and White 1969. Another new species, associated with an encephalitis of cattle, was described by W. E. Baillie (Ph.D. thesis, Kansas State Univ., Manhattan, 1969) as Haemophilus somnus; however, this name was not effectively published. The taxonomic position of this organism is uncertain because, although it resembles $H$. influenzae in appearing to require both $\mathrm{X}$ and $\mathrm{V}$ factors and in being indole positive, it resembles $H$. parainfluenzae in being oxidase positive and urease negative (see results reported below).

Haemophilus ducreyi (apparently illegitimate; the correct specific epithet according to Buchanan, Holt, and Lessel (8) is ulceris- 
cancrosi) is, on clinical grounds, a distinct species, and so is $H$. piscium Snieszko et al. 1950, although the latter may well belong in some other genus because it has a number of properties not found in other species of Haemophilus (7). H. vaginalis Gardner and Dukes 1955 is now usually considered to belong to some other genus $(13,41,67)$.

Type strains are available for only a few of these species, and this has been a major limitation of the present study. There is no type or neotype strain of the type species $H$. influenzae (Lehmann and Neumann 1896) Winslow et al. 1917, and although it must be admitted that the specific identity of the original strains would be hard to establish, the organism now given that name is well known, and numerous strains can be accepted as authentic.

\section{MATERIALS AND METHODS}

In the course of an investigation of the genus Bordetella and related genera (R. Johnson, Ph.D. thesis, Univ. of Leicester, England, 1972; reference 22), 29 strains of Haemophilus, representing all the species readily available to us, were studied (Table 1). It should be noted that the specific identity of some strains is uncertain (see Discussion) and that the strains are referred to here by the names under which they were received. It was noted that strains of species of Actinobacillus and Pasteurella came unexpectedly close to the Haemophilus strains, and results on these strains are therefore included in this report. The strains were examined for a wide range of characters, including morphology, colonial properties, growth requirements, resistance to various chemicals, attack on carbohydrates, and physiological and biochemical tests. $\mathrm{X}$ and $\mathrm{V}$ factors were added to media at concentrations of $2.5 \mathrm{mg} / \mathrm{liter}$, or were supplied as disks (Oxoid Ltd.) containing haemin $(10 \mu \mathrm{g})$, nicotinamide adenine dinucleotide $(10 \mu \mathrm{g})$, or both, placed on the surface of inoculated agar plates of medium lacking these factors, and incubated in air at 35 C. Details of the basal medium and methods are given by Johnson (Ph.D. thesis, Univ. of Leicester, England, 1972) and Johnson and Sneath (22). When a medium of low salt concentration was required, it was made up from its constituents omitting $\mathrm{NaCl}$ and contained only about $0.04 \% \mathrm{NaCl}$ derived from added serum. Carbohydrate tests could be satisfactorily made in the medium of Hugh and Leifson (19) with $30 \mathrm{mg}$ of bromothymol blue per liter as indicator if $2.5 \mathrm{mg}$ of haemin and of nicotinamide adenine dinucleotide per liter (sterilized by filtration) were added after autoclaving.

The results were coded as 134 characters; almost all were presence-absence characters, but a few quantitative characters were coded $0,1,2$, or 3 . The amount of experimental error, although not examined in detail for the Haemophilus strains, is believed to be only a few percent (see 56), and this is supported by the high level of similarity of $92 \%$ between $\mathrm{J} 73$ and $\mathrm{J} 74$, which are both derived from one strain, Pit tman $180 \mathrm{a}$.

Several different numerical taxonomic methods were employed. The findings described here are based on computations using the similarity coefficient of Gower (16), including negative matches (this is almost equivalent to a simple matching coefficient [see reference 59] when almost all characters are qualitative, as in the present study), followed by average-linkage cluster analysis (UPGMA, see reference 59 ). The other methods included computations omitting 22 carbohydrate fermentations, the coefficient $S_{J}$ (which excludes negative matches), the vigor coefficient, the pattern similarity coefficient $S_{P}$, and single-linkage clustering (see references 53 and 59). However, results from all of these on the Haemophilus strains were very similar, so that only a few points of interest revealed by them are mentioned.

\section{RESULTS}

The strains of Haemophilus fell into three fairly well-separated clusters (Fig. 1 and 2). These three groups formed at quite high $S$ levels, over $82 \%$, and they remained distinct until the similarity level fell to about $78 \%$. The fourth cluster contained the strains of Actinobacillus and Pasteurella. The properties of the four groups are shown in Table 2, from which the hypothetical median organisms (32) can be calculated. Although there was no clear separation between Actinobacillus and Pasteurella, the results for the two genera have for convenience been tabulated separately.

The four groups share the following salient and almost invariant properties: they are small, gram-negative rods or coccobacilli, nonmotile, often pleomorphic with filamentous forms, that are facultative anaerobes and ferment glucose anaerobically with the production of acid but no gas. They grow on blood agar (although Haemophilus strains grow poorly unless supplemented with $\mathrm{X}$ or $\mathrm{V}$ factors or in raised $\mathrm{CO}_{2}$ concentration when required), giving smooth, round, low, convex, or flattened colonies that are transparent or translucent, commonly showing some hemolysis on horse blood agar and occasionally slight greening. They are methyl red negative, Voges-Proskauer negative, and nonproteolytic, but are $\mathrm{H}_{2} \mathrm{~S}$ positive and phosphatase positive.

Cluster 1 contained all the strains of $H$. influenzae. The strains of $H$. aegyptius and $H$. haemoglobinophilus came into this group, and they may perhaps represent subgroups within this cluster because they link to the others at lower similarity levels than most of the strains in the cluster. However, the two strains of $H$. aegyptius are believed to derive from a single 
original isolate. The strain received as $H$. haemoglobinophilus also required $\mathrm{V}$ factor. haemolyticus also fell here.

None of the strains required added $\mathrm{CO}_{2}$ for

All the strains of this cluster required $X$ good growth. On horse blood agar containing factor, and all except the two strains of $H$. added $\mathrm{V}$ factor, or on chocolate agar (heated

TABLE 1. Strains studied

\begin{tabular}{|c|c|c|c|c|}
\hline Cluster & $\begin{array}{c}\text { Strain no. } \\
\text { in } \\
\text { this } \\
\text { survey }\end{array}$ & $\begin{array}{l}\text { Name as } \\
\text { received }\end{array}$ & $\begin{array}{l}\text { Source and } \\
\text { collection no. }\end{array}$ & Comments \\
\hline \multirow[t]{15}{*}{1} & J 73 & Haemophilus aegyptius & NCTC 8502 & $\begin{array}{l}\text { Proposed working type }{ }^{b}, \\
\text { Pittman } 180 \mathrm{a}\end{array}$ \\
\hline & J 74 & H. aegyptius & ATCC 11116 & $\begin{array}{l}\text { Another culture of } \\
\text { Pittman } 180 \mathrm{a}\end{array}$ \\
\hline & J 78 & H. haemoglobinophilus & NCTC 1659 & Co-type \\
\hline & J 79 & H. haemoglobinophilus & Zinnemann & \\
\hline & J 80 & H. haemolyticus & NCTC 8479 & $\begin{array}{l}\text { Proposed working type, } \\
\text { but see Discussion }\end{array}$ \\
\hline & J 83 & H. influenzae & NCTC 4560 & Proposed working type $e^{b}$ \\
\hline & J 86 & H. influenzae & ATCC 9006 & Pittman serotype a \\
\hline & J 87 & H. influenzae & NCTC 8645 & Pittman serotype a \\
\hline & J 88 & H. influenzae & NCTC 7279 & Pittman serotype b \\
\hline & J 89 & H. influenzae & NCTC 8496 & Pittman serotype $c$ \\
\hline & J 90 & H. influenzae & NCTC 8470 & Pittman serotype d \\
\hline & J 91 & H. influenzae & NCTC 8472 & Pittman serotype e \\
\hline & J 92 & H. influenzae & NCTC 7918 & Pittman serotype $\mathrm{f}$ \\
\hline & J 182 & Haemophilus sp. & PHLL & $\begin{array}{l}\text { Recent isolate from } \\
\text { human respiratory tract }\end{array}$ \\
\hline & J 183 & Haemophilus sp. & PHLL & $\begin{array}{l}\text { Recent isolate from } \\
\text { human respiratory tract }\end{array}$ \\
\hline \multirow[t]{11}{*}{2} & J 93 & Haemophilus suis & NCTC 4557 & $\begin{array}{l}\text { Co-type, but see } \\
\text { Discussion }^{b}\end{array}$ \\
\hline & J 94 & H. suis & CAPM 5111 & Pig lung, Czechoslovakia \\
\hline & J 95 & H. suis & CAPM 5113 & Pig lung, Czechoslovakia \\
\hline & J 99 & H. parainfluenzae & NCTC 4101 & \\
\hline & $\mathrm{J} 100$ & H. parainfluenzae & ATCC 7901 & \\
\hline & J 101 & H. parainfluenzae & ATCC 9796 & \\
\hline & J 102 & H. gallinarum & CAPM 5015 & Fowl, Canada, 1962 \\
\hline & J 103 & H. gallinarum & CAPM 5066 & Fowl, Czechoslovakia \\
\hline & J 104 & H. gallinarum & CAPM 5080 & Fowl, Czechoslovakia \\
\hline & J 108 & $H$. parasuis & CAPM 5114 & \\
\hline & J 125 & Haemophilus sp. & CAPM P392 & \\
\hline \multirow[t]{3}{*}{3} & J 75 & Haemophilus aphrophilus & NCTC 5886 & Holotype $^{b}$ \\
\hline & J 120 & H. aphrophilus & NCTC 5906 & A co-type (see 4) \\
\hline & J 121 & H. paraphrophilus & NCTC 10557 & Holotype (65) \\
\hline \multirow[t]{9}{*}{4} & J 19 & Actinobacillus equuli & NCTC 8529 & Proposed working ty pe $\mathrm{e}^{b}$ \\
\hline & J 20 & A. lignieresii & NCTC 4975 & \\
\hline & J 21 & A. lignieresii & NCTC 4976 & Proposed working ty pe ${ }^{b}$ \\
\hline & J 167 & Pasteurella multocida & NCTC 3195 & Proposed working type ${ }^{b}$ \\
\hline & J 169 & P. pneumotropica & NCTC 8141 & \\
\hline & J 170 & P. ureae & NCTC 10222 & \\
\hline & J 171 & $P$. haemolytica & NCTC 10365 & Type A of Smith $(50,51)$ \\
\hline & J 245 & P. piscicida & ATCC 17911 & Co-type $(21)$ \\
\hline & J 246 & P. ureae & PHLL & \\
\hline
\end{tabular}

$a$ Abbreviations: ATCC, American Type Culture Collection, Rockville, Md.; CAPM, Collection of Animal Pathogenic Microorganisms, Brno-Medlánky, Czechoslovakia; NCTC, National Collection of Type Cultures, London; PHLL, Public Health Laboratory, Leicester, England; Zinnemann, K. Zinnemann, Department of Bacteriology, School of Medicine, Leeds, England.

$b$ From Sneath and Skerman (57). 
blood agar), and after $48 \mathrm{~h}$ at $35 \mathrm{C}$ the colonies were 0.5 to $2.0-\mathrm{mm}$ in diameter, circular, low conical or flat topped, often with a central umbo and bevelled edge. The edge was entire or occasionally slightly lobed and often with radial striations on the bevel. The surface was smooth or undulant, and shiny. The growth was colorless or slightly gray, translucent, and butyrous. There was no pitting around the colony (i.e., the edge was not sunken below the agar surface). On blood agar, beta hemolysis was scanty or absent (except for the hemolytic strain J80), but there was often some green discoloration of the medium. On blood agar without $\mathrm{V}$ factor, colonies were 0.3 to $0.5-\mathrm{mm}$ in diameter, low convex or only slightly flattened, and showed marked satellitism around $\mathrm{V}$ factor disks or plate contaminants (except for strains J78 and J79). Cultures had a pronounced smell of amines, similar to putrescine.

Cluster 2 contained the strains received as $H$. parainfluenzae, $H$. suis, and $H$. gallinarum as well as one unidentified strain. All of these required $\mathrm{V}$ factor but not $\mathrm{X}$ factor. They did not require added $\mathrm{CO}_{2}$ for good growth. On horse blood agar with $\mathrm{V}$ factor, or on chocolate agar, colonies were similar to those of strains of cluster 1 except in the following. They were seldom umbonate, and the edge was not bevelled and was without radial striations. The surface was somewhat smoother, and the

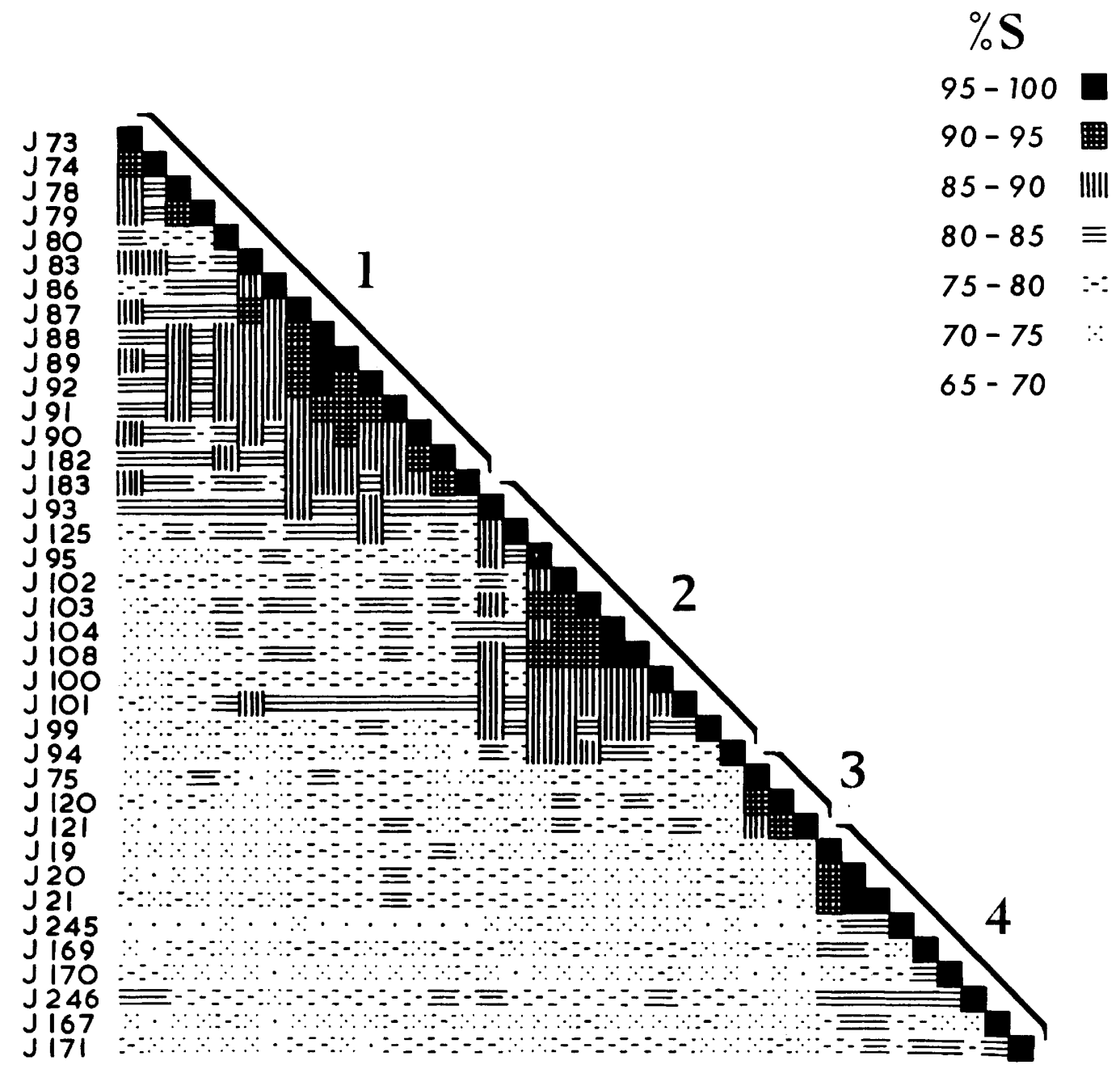

FIG. 1. Shaded similarity matrix of strains of Actinobacillus, Haemophilus and Pasteurella /Gower's similarity coefficient including negative matches). 


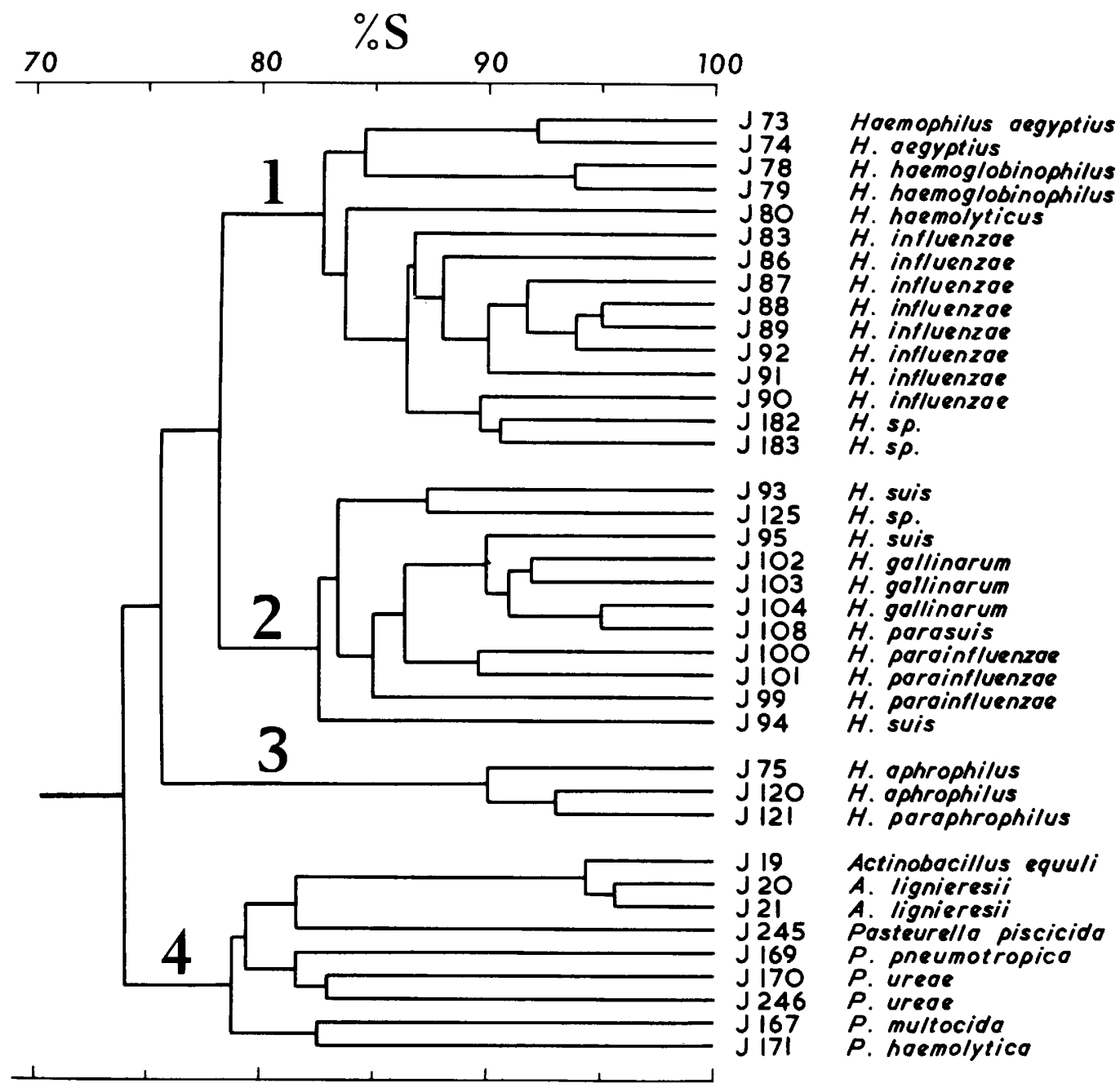

FIG. 2. Phenogram of strains of Actinobacillus, Haemophilus, and Pasteurella (UPGMA clustering of similarities from Fig. 1). The co-phenetic correlation coefficient is 0.84 .

growth was sometimes semiopaque, commonly tinged pale yellow. Hemolysis and green discoloration was still less marked, but satellitism and the smell of amines were both present.

Cluster 3 contained $H$. aphrophilus and $H$. paraphrophilus. The two strains of the former required $\mathrm{X}$ but not $\mathrm{V}$ factor (though $H$. aphrophilus mutates regularly to $\mathrm{X}$-independence [see reference 5]), whereas the latter required $\mathrm{V}$ but not $\mathrm{X}$. Nevertheless, the two species are otherwise very similar. All three strains require added $\mathrm{CO}_{2}$ for good growth even in the presence of $\mathrm{X}$ plus $\mathrm{V}$ factor (the $\mathrm{CO}_{2}$ concentration was $5 \%$ in air; the basal medium contained a low level of sodium chloride, about $0.04 \%$ ). On horse blood agar with $\mathrm{V}$ factor, or on chocolate agar, incubated in $5 \% \mathrm{CO}_{2}$, the colonies were similar to those of cluster 1 except in the following ways. They were high convex, not flattened or umbonate, with an entire edge without radial strictions or bevel, and the growth was translucent, gray or yellowish, and that of strain $\mathrm{J} 121$ was viscid. Hemolysis was slight, though on long incubation $\mathrm{J} 121$ gave partial beta hemolysis with some green discoloration. In the absence of added $\mathrm{CO}_{2}$, colonies were minute, and satellitism was only shown by $\mathrm{J} 121$. The cultures did not smell of amines. The only significant discrepancies from the original species descriptions $(27,65)$ was that strains $\mathrm{J} 75$ and $\mathrm{J} 120$ acidified fructose and galactose. 
TABLE 2. Characters of groups as percentage of positive reactions ${ }^{a}$

\begin{tabular}{|c|c|c|c|c|c|}
\hline Character & $\begin{array}{l}\text { Actino- } \\
\text { bacillus } \\
\qquad(3)^{b}\end{array}$ & Pasteurella (6) & $\begin{array}{c}\text { Haemophilus } \\
\text { influenzae } \\
\text { group (15) }\end{array}$ & $\begin{array}{c}\text { Haemophilus } \\
\text { parainfluenzae } \\
\text { group (11) }\end{array}$ & $\begin{array}{c}\text { Haemophilus } \\
\text { aphrophilus } \\
\text { group (3) }\end{array}$ \\
\hline Gram reaction ( 2 days) & $0^{c}$ & 0 & 0 & 0 & 0 \\
\hline Retention of methyl violet ( 2 days) & 0 & 50 & 0 & 0 & 0 \\
\hline Chains or filaments present ( 2 days) & 100 & 33 & 73 & 100 & 33 \\
\hline Pleomorphism (2 days) & 100 & 33 & 73 & 100 & 33 \\
\hline Cocci or coccobacilli (2 days) & 100 & 33 & 0 & 0 & 33 \\
\hline Colony opaque & 0 & 33 & 0 & 0 & 0 \\
\hline Colony viscid & 100 & 0 & 0 & 0 & 0 \\
\hline Pellicle on broth & 67 & 33 & 0 & 0 & 0 \\
\hline Diffusible brown pigment & 0 & 0 & 0 & 0 & 0 \\
\hline Pigment from tyrosine & 0 & 0 & 0 & 0 & 0 \\
\hline Dextran or levan production & 0 & 0 & 0 & 0 & 0 \\
\hline Growth anaerobically & 100 & 100 & 100 & 100 & 100 \\
\hline Growth anerobically with nitrate & 100 & 100 & 100 & 100 & 100 \\
\hline $\mathrm{CO}_{2}$ requirement & 0 & 0 & 0 & 0 & 100 \\
\hline $\mathrm{X}$ factor requirement & 0 & 0 & 100 & 0 & 67 \\
\hline $\mathrm{V}$ factor requirement & 0 & 0 & 87 & 100 & 33 \\
\hline Growth on nutrient agar & 100 & 100 & 0 & 0 & 0 \\
\hline Growth on blood agar & 100 & 100 & 100 & 100 & 100 \\
\hline Hemolysis of horse red cells & 0 & $67^{d}$ & 47 & 27 & 0 \\
\hline Hemolysis of sheep red cells & 0 & 0 & 7 & 0 & 0 \\
\hline Motility (14 days) & 0 & 0 & 0 & 0 & 0 \\
\hline Growth on $5 \%$ bile salts & 100 & 67 & 53 & 55 & 100 \\
\hline Growth on $10 \%$ bile salts & 0 & 17 & 7 & 27 & 0 \\
\hline Growth on $40 \%$ bile salts & 0 & 0 & 0 & 0 & 0 \\
\hline Growth on $0 \% \mathrm{NaCl}$ & 100 & 67 & 100 & 100 & 100 \\
\hline Growth on $3 \% \mathrm{NaCl}$ & 67 & 67 & 0 & 55 & 0 \\
\hline Growth on $4.5 \% \mathrm{NaCl}$ & 0 & 0 & 0 & 0 & 0 \\
\hline Growth on $6 \% \mathrm{NaCl}$ & 0 & 0 & 0 & 0 & 0 \\
\hline Growth on $7.5 \% \mathrm{NaCl}$ & 0 & 0 & 0 & 0 & 0 \\
\hline Growth on $9 \% \mathrm{NaCl}$ & 0 & 0 & 0 & 0 & 0 \\
\hline Growth on $0.1 \%$ phenol agar & 0 & 50 & 7 & 0 & 0 \\
\hline Growth on $0.2 \%$ phenol agar & 0 & 0 & 0 & 0 & 0 \\
\hline Growth on $0.3 \%$ phenol agar & 0 & 0 & 0 & 0 & 0 \\
\hline Growth on $0.4 \%$ phenol agar & 0 & 0 & 0 & 0 & 0 \\
\hline Growth on $0.5 \%$ phenol agar & 0 & 0 & 0 & 0 & 0 \\
\hline $\begin{array}{l}\text { Growth on } 320 \mathrm{mg} \text { of potassium } \\
\text { tellurite per liter }\end{array}$ & 0 & 0 & 13 & 0 & 0 \\
\hline $\begin{array}{l}\text { Growth on } 75 \mathrm{mg} \text { of sodium azide } \\
\text { per liter }\end{array}$ & 100 & 100 & 100 & 100 & 100 \\
\hline Growth on $0.5 \%$ thallous acetate & 0 & 0 & 13 & 9 & 0 \\
\hline $\begin{array}{l}\text { Growth on } 12.5 \mathrm{mg} \text { of M and B } 938 \\
\text { per liter }\end{array}$ & 0 & 67 & 13 & 82 & 0 \\
\hline Growth on $0.5 \%$ sodium nitrite & 100 & 100 & 13 & 45 & 0 \\
\hline Growth at $5 \mathrm{C}$ (10 days) & 0 & 0 & 0 & 0 & 0 \\
\hline Growth at $10 \mathrm{C}(10$ days $)$ & 0 & 0 & 0 & 9 & 0 \\
\hline Growth at $15 \mathrm{C}$ (10 days) & 100 & 33 & 0 & 18 & 0 \\
\hline Growth at $25 \mathrm{C}$ ( 10 days) & 100 & 100 & 100 & $91^{d}$ & $100^{d}$ \\
\hline Growth at $35 \mathrm{C}$ (10 days) & 100 & 100 & 100 & 100 & 100 \\
\hline Growth at $37 \mathrm{C}$ (10 days) & 100 & 83 & 100 & 100 & 100 \\
\hline Growth at $44 \mathrm{C}$ (10 days) & 0 & 0 & 7 & 64 & 0 \\
\hline Sensitivity to penicillin & 100 & 100 & 93 & 64 & 100 \\
\hline
\end{tabular}

Cluster 4 contained the strains of Actinobacillus and Pasteurella, which are associated at a level of over $75 \% \mathrm{~S}$. Although the strains of Actinobacillus equuli and $A$. lignieresii fall together (and are indeed extremely similar), there is here no strong evidence that Actinobacillus forms a genus distinct from Pasteurella (see Discussion). They did not require $\mathrm{X}$ or $\mathrm{V}$ 
TABLE 2-Continued

\begin{tabular}{|c|c|c|c|c|c|}
\hline Character & $\begin{array}{l}\text { Actino- } \\
\text { bacillus } \\
(3)^{b}\end{array}$ & Pasteurella (6) & $\begin{array}{c}\text { Haemophilus } \\
\text { influenzae } \\
\text { group (15) }\end{array}$ & $\begin{array}{c}\text { Haemophilus } \\
\text { parainfluenzae } \\
\text { group (11) }\end{array}$ & $\begin{array}{c}\text { Haemophilus } \\
\text { aphrophilus } \\
\text { group (3) }\end{array}$ \\
\hline Sensitivity to streptomycin & 100 & 100 & 100 & 100 & 100 \\
\hline Sensitivity to chloramphenicol & 100 & 100 & 100 & 91 & 100 \\
\hline Sensitivity to aureomycin & 100 & 100 & 100 & 100 & 100 \\
\hline Sensitivity to terramycin & 100 & 100 & 100 & 100 & 100 \\
\hline Sensitivity to erythromycin & 100 & 100 & 100 & 73 & 33 \\
\hline Sensitivity to tetracycline & 100 & 100 & 100 & 91 & 100 \\
\hline Sensitivity to sulfonamide & 100 & 50 & 27 & 0 & 100 \\
\hline Sensitivity to neomycin & 100 & 100 & 100 & 100 & 100 \\
\hline Sensitivity to novobiocin & 100 & 100 & 100 & 100 & 100 \\
\hline Sensitivity to oleandomycin & 100 & 100 & 100 & 100 & 100 \\
\hline Sensitivity to nitrofurantoin & 100 & 100 & 100 & 100 & 100 \\
\hline Sensitivity to bacitracin & 0 & 0 & 0 & 0 & 0 \\
\hline Sensitivity to Bactrim Roche & 100 & 100 & 7 & 9 & 33 \\
\hline Sensitivity to $0 / 129$ & 67 & 83 & 33 & 0 & 67 \\
\hline Sensitivity to thionine & 0 & 17 & 27 & 0 & 0 \\
\hline Sensitivity to basic fuchsin & 67 & 67 & 93 & 9 & 0 \\
\hline Sensitivity to methyl violet & 100 & 50 & 93 & 36 & 0 \\
\hline Sensitivity to safranine & 33 & 17 & 40 & 45 & 0 \\
\hline Sensitivity to pyronin & 100 & 50 & 53 & 9 & 0 \\
\hline Heat resistance: $56 \mathrm{C}, 5 \mathrm{~min}$ & 33 & 67 & 53 & 91 & 33 \\
\hline Heat resistance: $56 \mathrm{C}, 10 \mathrm{~min}$ & 0 & 33 & 33 & 82 & 33 \\
\hline Heat resistance: $56 \mathrm{C}, 15 \mathrm{~min}$ & 0 & 33 & 20 & 64 & 0 \\
\hline Heat resistance: $56 \mathrm{C}, 20 \mathrm{~min}$ & 0 & 0 & 13 & 36 & 0 \\
\hline Catalase (2 days) & 100 & 83 & 100 & 91 & 0 \\
\hline Peroxidase ( 2 days) & 100 & 67 & 0 & 9 & 0 \\
\hline Oxidase ( 2 days) & 100 & 100 & 7 & 73 & 0 \\
\hline $\mathrm{H}_{2} \mathrm{~S}$ production & 100 & 100 & 100 & 100 & 100 \\
\hline Phosphatase (5 days) & 100 & 100 & 80 & 100 & 100 \\
\hline Gelatin hydrolysis & 0 & 0 & 0 & 0 & 0 \\
\hline Starch hydrolysis & 100 & 100 & 33 & $100^{d}$ & 0 \\
\hline Turbidity from egg yolk & 0 & 0 & 0 & 0 & 0 \\
\hline Casein hydrolysis & 0 & 0 & 0 & 0 & 0 \\
\hline Aesculin hydrolysis & 0 & 0 & 7 & 0 & 0 \\
\hline Tetrazolium reduction & 100 & 100 & 100 & 100 & 100 \\
\hline Indole production & 0 & 0 & 53 & 0 & 0 \\
\hline Ammonia from peptone & $100^{d}$ & 67 & 80 & $73^{d}$ & $100^{d}$ \\
\hline Urease $(1 \mathrm{~h})$ & 100 & 50 & 87 & 0 & 0 \\
\hline Arginine hydrolysis (1 day) & 0 & 50 & 7 & 0 & 0 \\
\hline Nitrate reduction & 100 & 50 & 67 & 82 & 100 \\
\hline Deoxyribonuclease & 0 & 0 & 0 & 0 & 0 \\
\hline Methyl red & 0 & 17 & 20 & 55 & 0 \\
\hline Voges Proskauer & 0 & 0 & 0 & 0 & 0 \\
\hline Tyrosine hydrolysis & 0 & 0 & 0 & 0 & 0 \\
\hline Xanthine hydrolysis & 0 & 0 & 0 & 0 & 0 \\
\hline Phenylalanine deaminase & 0 & 0 & 0 & 0 & 0 \\
\hline Tween 20 hydrolysis & 0 & 0 & 0 & 0 & 0 \\
\hline Tween 40 hydrolysis & 0 & 0 & 0 & 0 & 0 \\
\hline Tween 60 hydrolysis & 0 & 0 & 0 & 0 & 0 \\
\hline Tween 80 hydrolysis & 0 & 0 & 0 & 0 & 0 \\
\hline Clearing of Tween 80 & 33 & 0 & 0 & 0 & 0 \\
\hline Acid aerobically from $1 \%$ glucose & 100 & 100 & 100 & 100 & 100 \\
\hline Acid anaerobically from $1 \%$ glucose & 100 & 100 & 100 & 100 & 100 \\
\hline Acid aerobically from $10 \%$ glucose & 100 & 100 & 0 & 0 & 100 \\
\hline Acid aerobically from $1 \%$ lactose & 0 & 0 & 0 & 0 & 100 \\
\hline Acid aerobically from $10 \%$ lactose & 0 & 0 & 0 & 0 & 100 \\
\hline Alkali aerobically from $1 \%$ lactose & 0 & 33 & 0 & 0 & 0 \\
\hline Acid aerobically from xylose & 100 & 33 & 40 & 9 & 0 \\
\hline Acid aerobically from salicin & 0 & 0 & 0 & 0 & 0 \\
\hline Acid aerobically from raffinose & 0 & 17 & 0 & 0 & 0 \\
\hline $\begin{array}{l}\text { Acid aerobically from methyl-D- } \\
\text { glucoside }\end{array}$ & 0 & 0 & 0 & 0 & 0 \\
\hline
\end{tabular}


TABLE 2-Continued

\begin{tabular}{|c|c|c|c|c|c|}
\hline Character & $\begin{array}{c}\text { Actino- } \\
\text { bacillus } \\
(3)^{b}\end{array}$ & Pasteurella (6) & $\begin{array}{c}\text { Haemophilus } \\
\text { influenzae } \\
\text { group (15) }\end{array}$ & $\begin{array}{l}\text { Haemophilus } \\
\text { parainfluenzae } \\
\text { group (11) }\end{array}$ & $\mid \begin{array}{c}\text { Haemophilus } \\
\text { aphrophilus } \\
\text { group (3) }\end{array}$ \\
\hline Acid aerobically from ribose & 100 & 67 & 27 & 55 & 100 \\
\hline Acid aerobically from rhamnose & 0 & 0 & 0 & 0 & 0 \\
\hline Acid aerobically from mannose & 100 & 100 & 0 & 73 & 100 \\
\hline Acid aerobically from inositol & 0 & 33 & 0 & 0 & 0 \\
\hline Acid aerobically from cellobiose & 0 & 0 & 0 & 0 & 100 \\
\hline Acid aerobically from fructose & 100 & 50 & 20 & 100 & 100 \\
\hline Acid aerobically from $L(+)$ arabinose & 100 & 17 & 0 & 55 & 0 \\
\hline Acid aerobically from dextrin & 100 & 83 & 87 & 91 & 67 \\
\hline Acid aerobically from sorbitol & 0 & 50 & 0 & 0 & 0 \\
\hline Acid aerobically from galactose & 100 & 100 & 60 & 73 & 100 \\
\hline Acid aerobically from maltose & 100 & 100 & 60 & 55 & 100 \\
\hline Acid aerobically from sucrose & 0 & 100 & 0 & 82 & 100 \\
\hline Acid aerobically from mannitol & 100 & 83 & 0 & 9 & 0 \\
\hline Acid aerobically from glycerol & 0 & 33 & 0 & 18 & 100 \\
\hline Acid aerobically from glucosamine & 0 & 83 & 100 & 100 & 100 \\
\hline Acid aerobically from inulin & 0 & 0 & 7 & 55 & 100 \\
\hline Acid aerobically from adonitol & 0 & 0 & 0 & 0 & 0 \\
\hline
\end{tabular}

${ }^{a}$ All strains grew on $0.5 \% \mathrm{NaCl}$, at $30 \mathrm{C}$, and in the presence of optochin, and none produced hydrogen cyanide or acid from dulcitol.

$b$ Number of strains studied indicated in parentheses.

$c$ Symbols: figures indicate the percentage of strains positive within 7 days (unless otherwise noted).

$d$ Weak but definite reactions.

factors or a raised $\mathrm{CO}_{2}$ tension for growth. On horse blood agar and chocolate agar the colonial morphology was variable as would be expected, but the colonies were all large $(1.5-3.0 \mathrm{~mm}$ after $48 \mathrm{~h}$ at $35 \mathrm{C})$, they were usually low conical, smooth, shiny or matte, sometimes umbonate, and had no bevelled edge (except J169). Growth was grayish and transparant to semiopaque. J20 and J21 showed slight but definite pitting, with the edge sunken below the surface of the medium, and, together with $\mathrm{J} 19$, gave viscid colonies. Hemolysis was often noticeable, usually beta in type with some green or brown discoloration. There was no satellitism, and cultures did not have the characteristic smell of cluster 1 strains.

Table 3 shows the mean inter- and intragroup $S$ values for these four clusters. Included in the tables are the values for "vigor" (53), which is one index of metabolic activity. It is seen that the strains of the Actinobacillus-Pasteurella cluster are appreciably more active than those of the Haemophilus clusters. The vigor differences between the Haemophilus clusters are not statistically significant by the $t$ test at the 5\% confidence level, with one exception: strains of cluster 1 are significantly less active than those of cluster 2. Because the vigor differences between the Haemophilus clusters are so small, the pattern similarity coefficient $S_{P}$ (that provides some correction for discrepancies in
TABLE 3. Mean intergroup and intragroup percentage $S$ values, and vigor, with their standard deviations

\begin{tabular}{l|c|c|c|c|c}
\hline \multirow{2}{*}{ Clusters } & \multicolumn{5}{|c}{ Percentage $S$ values } \\
\cline { 2 - 6 } & $1^{a}$ & 2 & 3 & 4 & Vigor \\
\hline 1 & 85.43 & & & & 0.394 \\
& $(3.95)$ & & & & $(0.028)$ \\
2 & 78.39 & 85.81 & & & 0.430 \\
& $(3.49)$ & $(3.87)$ & & & $(0.026)$ \\
3 & 75.09 & 78.39 & 91.20 & & 0.414 \\
4 & $(3.20)$ & $(3.49)$ & $(2.29)$ & & $(0.034)$ \\
& 73.91 & 74.93 & 71.23 & 80.87 & 0.485 \\
& $(3.61)$ & $(2.41)$ & $(2.90)$ & $(5.09)$ & $(0.020)$ \\
\hline
\end{tabular}

${ }^{a}$ Clusters.

vigor, growth rate, incubation temperature, and the like, see reference 59) gave results almost identical to those shown in Fig. 1 and 2. The three Haemophilus clusters were unchanged except for minor rearrangement within them, and they appeared somewhat more compact and distinct. The Actinobacillus-Pasteurella cluster was still closer to the Haemophilus clusters; within it there was slight rearrangement, but there was one aberrant result-strain $\mathrm{J} 167$ ( $P$. multo cida) appeared outside the group among a residue of poorly characterized organisms peripheral to Yersinia strains that are not 
considered in the present report. Also, a strain J153 (=ATCC 11479) received by us under the name of Noguchia granulosis, but possibly not an authentic strain (22), became a satellite of the Actinobacillus-Pasteurella-Haemophilus complex.

Omission of 22 carbohydrate fermentations (but still using Gower's coefficient and UPGMA) again made very little difference. The Haemophilus clusters were practically unchanged. Cluster 4 showed some rearrangement, but the only notable feature was that a strain of Pasteurella haemolytica type T $(50,51), \mathrm{J} 172$ (=NCTC 10371), moved into this cluster from a position peripheral to Yersinia. Again Noguchia granulosis was a satellite of the ActinobacillusHaemophilus-Pasteurella complex. The major division of this complex from other genera of Brucellaceae was maintained (22).

The differences with change of the computing method mentioned above are relatively small, and a glance at the strains that moved in or out of the four clusters shows them to be single representatives of bacterial species; they also may well be peripheral to the main groups studied here or intermediate between them. They are thus quite likely to show some instability.

The genera Actinobacillus, Haemophilus, and Pasteurella share a number of characters. They are non motile; they grow anaerobically and produce acid anaerobically from $1 \%$ glucose; they usually grow on agar without $\mathrm{NaCl}$ but do not grow on $4.5 \% \mathrm{NaCl}$ agar; they are phosphatase positive, produce $\mathrm{H}_{2} \mathrm{~S}$ readily, and seldom hydrolyze Tween 80 or arginine. Closely related genera such as Alcaligenes, Bordetella, Brucella, and Moraxella differ in most of these characters, but the differences from Yersinia are fewer. However Yersinia strains generally grow on $4.5 \% \mathrm{NaCl}$, hydrolyze arginine, and are phosphatase negative. In addition Yersinia strains produce a characteristic clearing in plates containing $1 \%$ Tween 80

TABLE 4. Differential features of clusters

\begin{tabular}{|c|c|c|c|c|}
\hline Characters & $\begin{array}{c}1 \\
\text { Haemophilus } \\
\text { influenzae } \\
\text { group } \\
\text { (cluster 1) }\end{array}$ & $\begin{array}{c}2 \\
\text { Haemophilus } \\
\text { parainfluenzae } \\
\text { group } \\
\text { (cluster 2) }\end{array}$ & $\begin{array}{c}3 \\
\text { Haemophilus } \\
\text { aphrophilus } \\
\text { group } \\
\text { (cluster 3) }\end{array}$ & $\begin{array}{c}4 \\
\text { Actino- } \\
\text { bacillus- } \\
\text { Pasteurella } \\
\text { group (cluster 4) }\end{array}$ \\
\hline Growth on nutrient agar in air & $-^{a}$ & - & - & + \\
\hline $\mathrm{X}$ factor requirement & + & - & $\mathrm{v}$ & - \\
\hline $\mathrm{V}$ factor requirement & $\mathrm{v}$ & + & $\mathrm{v}$ & - \\
\hline $\begin{array}{l}\mathrm{CO}_{2} \text { requirement on low } \\
\mathrm{NaCl} \text { medium }\end{array}$ & - & - & + & - \\
\hline $\begin{array}{l}\text { Sensitivity to basic fuchsin, } \\
1 / 200,000^{b}\end{array}$ & + & - & - & $v$ \\
\hline Sensitivity to $0 / 129^{c}$ & $\mathrm{v}$ & - & $\mathbf{v}$ & + \\
\hline Sensitivity to M\&B $938^{d}$ & + & - & + & $\mathbf{v}$ \\
\hline Catalase & + & + & - & + \\
\hline Oxidase $^{e}$ & - & $\mathrm{v}$ & - & + \\
\hline Urease & + & - & - & $\mathbf{v}$ \\
\hline Nitrate reduction & $\mathrm{v}$ & + & + & $v$ \\
\hline Indole production & $\mathrm{v}$ & - & - & - \\
\hline Starch hydrolysis & $\mathbf{v}$ & $\mathrm{v}$ & - & + \\
\hline Acid from $1 \%$ lactose & - & - & + & - \\
\hline Acid from $1 \%$ fructose & - & + & + & $v$ \\
\hline Acid from $1 \%$ arabinose & - & $\mathbf{v}$ & - & $\mathrm{v}$ \\
\hline Acid from $1 \%$ cellobiose & - & - & + & - \\
\hline Acid from $1 \%$ sucrose & - & + & + & $\mathbf{v}$ \\
\hline Acid from $1 \%$ mannitol & - & - & - & + \\
\hline Acid from $10 \%$ glucose & - & - & + & + \\
\hline
\end{tabular}

${ }^{a}$ Symbols: + , more than $80 \%$ of strains positive within 7 days; - , less than $20 \%$ of strains positive within 7 days; $v$, between 20 and $80 \%$ of strains positive within 7 days.

$b$ Filter paper strip (Whatman no. 1), $0.5-\mathrm{cm}$ wide soaked in $1 / 200,000$ aqueous solution $(5 \mu \mathrm{g} / \mathrm{ml}$ ) and dried, incorporated into heated blood agar plates, and cross-streaked with organism.

$c$ Paper disk containing $40 \mu \mathrm{g}$ of 2,4-diamino, 6,7 di-iso-propyl pteridine.

${ }^{d}$ Basal medium containing $12.5 \mathrm{mg} / \mathrm{ml}$ of $4: 4^{\prime}$ diamidinodiphenylamine dihydrochloride.

${ }^{e}$ Method of Kovacs (28) read after $10 \mathrm{~s}$. 
that is not shown by organisms of the Actinobacillus-Haemophilus-Pasteurella group or by most of the other genera mentioned, although Alcaligenes and Bordetella bronchiseptica do show this clearing (22).

The features that distinguish the four clusters of the Actinobacillus-Haemophilus-Pasteurella group are shown in Table 4. Carbohydrate tests in the Hugh and Leifson medium were more sensitive than the method used for the computer analysis (in which indicator was added only after incubation because of the risk of inhibition of Bordetella pertussis strains in the other part of this survey). With Hugh and Leifson medium, all strains in clusters 2 and 3 , but few strains of cluster 1 , acidified mannose and galatose. Two-thirds of the strains in cluster 1 but only one-third of the strains of cluster 2 acidified xylose in this medium. Most strains of cluster 2 acidified raffinose in this medium. Fewer positives were obtained in this medium with dextrin than by the other technique. Otherwise the carbohydrate tests were in good agreement.

\section{DISCUSSION}

Haemophilus appears to be an acceptable genus because the three clusters of strains in this genus are quite similar, and they unite before being joined by the ActinobacillusPasteurella cluster. The three genera are evidently close, although there appears to be no critical evidence from genetics or serology to support this (23). They do not greatly differ in deoxyribonucleic acid base composition, having $\mathrm{G} / \mathrm{C}$ ratios in the 35 to $45 \%$ range $(17,18$, 44).

Even though it is difficult to base conclusions on the results of such a small number of strains, the data provide quite strong evidence against the separation of Actinobacillus and Pasteurella as distinct genera. It has been known for many years that Actinobacillus lignieresii and Pasteurella multocida are phenetically very similar (55), and more recently Mraz $(33,34,35)$ has given further evidence of the close similarity of both $\mathrm{A}$ and $\mathrm{T}$ types of $P$. haemolytica to $A$. lignieresii. It may be noted that it is difficult to identify individual strains as to genus until after they have been identified to species. If after further study it is considered best to combine the genera, the name Pasteurella would apply, as it is the older name $(8,24)$.

There is certainly doubt about the generic identity of some of the strains we studied. However, the strains of $H$. haemoglobinophilus required only $X$ factor as expected (42), and one of them was a type strain. Similarly, $H$. aphrophilus and $H$. paraphrophilus were represented by type strains, which agreed with the original descriptions on all major points. Strain $\mathrm{J} 75$ (=NCTC 5886) is the type strain of $H$. aphrophilus by monotypy, as it was the only strain described in the original publication of Khairat (27); it cannot therefore be replaced as atypical (5) unless evidence is adduced that it is not authentic or does not agree with the original description. There are said to be other isolations of the same strain from the same case of disease, and J120 is one of these, but it is puzzling that they appear to differ in several ways (4). There may be, therefore, some doubt on the generic authenticity of both J75 and $\mathrm{J} 120$, and in our hands they were very similar but not quite identical.

Two species, $H$. suis and $H$. gallinarum, raise problems that have been discussed at some length by Biberstein and White (3). H. suis is not a legitimate name according to Buchanan, Holt, and Lessel (8), and it should be named $H$. influenzae-suis Lewis and Shope 1931. The original isolates required both $\mathrm{X}$ and $\mathrm{V}$ factors $(31,47)$, but most strains from swine require only $\mathrm{V}$ factor $(2,63)$. Lewis and Shope make it clear that their strains were virtually indistinguishable from indole-negative strains of $H$. influenzae. They were nonhemolytic. It appears very likely that later isolates that required only $\mathrm{V}$ factor (e.g., 30) belonged to a different species, most probably a member of the $H$. parainfluenzae group represented by cluster 2 . Strain $\mathrm{J} 93$ is recorded $(36,57)$ as an original strain of Lewis and Shope, but in view of the fact that it does not require $\mathrm{X}$ factor and possesses most of the other characteristics of cluster 2 , its authenticity as a co-type strain must be considered very doubtful.

The situation with $H$. gallinarum is similar. The original organism on which this name was based was not that of de Blieck (9), although de Blieck's organism has been cited (7) as that on which the species was founded. Delaplane, Erwin, and Stuart (10) state that they believed de Blieck's organism was the same as the cultures they studied, for which they proposed the name $H$. gallinarum, but it is clear from their text that the new species was founded on an organism briefly described by Nelson (37) and on strain R.I., which they isolated themselves. They wrote: "We have not been able to study the $B$. haemoglobinophilus coryza gallinarum (DeBlieck) in our laboratory, but from certain morphological and cultural characteristics, we believe it to be identical to culture 
5080 of Nelson and the R.I. strain of organisms for which we suggest the name Hemophilus gallinarum." In their first publication, the exact $\mathrm{X}$ and $\mathrm{V}$ requirements are difficult to infer, but the strains definitely required $X$ factor and probably also $\mathrm{V}$ factor (because of the poor growth stimulation with blood that had been stored for a long period). The strains only grew well in a closed, humid container, reminiscent of the behavior of $H$. paraphrophilus (14).

In later publications $(11,12), H$. gallinarum was found definitely to require both $\mathrm{X}$ and $\mathrm{V}$ factors and to have an obligate requirement for sodium chloride $(0.5-2.5 \%)$. In view of the accumulation of $\mathrm{CO}_{2}$ in closed containers and the sparing action of sodium chloride on the $\mathrm{CO}_{2}$ requirement of the $H$. aphrophilus group (65), the growth requirements of $H$. gallinarum deserve deeper investigation if authentic strains can be obtained. However, other workers have isolated fowl strains that are almost indistinguishable from $H$. parainfluenzae (see reference 3 for a discussion), as are the strains we received as $H$. gallinarum. These also did not show the sodium-chloride requirement characteristic of $H$. gallinarum (7). Again, our strains cannot be regarded as authentic strains of this species.

Strain J80 (=NCTC 8479 ) of H. haemolyticus was received directly from the National Collection of Type Cultures, and evidently it is not the same as a strain bearing this number mentioned by Biberstein and Zinnemann (4) as requiring $\mathrm{V}$ but not $\mathrm{X}$ factor. In our hands $\mathrm{J} 80$ required both $\mathrm{X}$ and $\mathrm{V}$ factors and had more of the other characters of cluster 1 than of cluster 2 , but it should be noted that the species $H$. haemolyticus Bergey et al. 1923 was founded on the beta-haemolytic "Bacillus X" of Pritchett and Stillman (40), whose exact $X$ and $\mathrm{V}$ requirements were not determined. How ever, Stillman and Bourn (61) describe carbohydrate reactions (frequent acidity from fructose and sucrose) that are more typical of cluster 2 than of cluster 1, and J80 was exceptional among strains of cluster 1 in producing acidity from both of these. Taken in conjunction with the rather low level at which $\mathrm{J} 80$ joins cluster 1, this suggests that $H$. haemolyticus might be a subgroup within cluster 1 .

No type strain of Haemophilus parainfluenzae is available, but the strains we received under this name appear to be authentic and to agree well with the original description of Rivers (43) of his two nonhaemolytic strains that required only $V$ factor.

Fortunately many of these problems need not be faced until more is known of what phenetic groups exist within the genus. The present investigation was seriously limited because of the relatively few strains available for study, and work on additional strains is clearly needed. There may have been a tendency in the past to establish species of Haemophilus on slender grounds, utilizing single characters of uncertain significance, such as haemolysis or host of origin. In some cases no strains were listed when species were set up, so that in the event of any confusion the choice of type strains is likely to be arbitrary. The present survey suggests that haemolysis is an inadequate criterion for speciation. Host of origin is never a very satisfactory criterion, and the fact that cluster 2 contains human, swine, and fowl strains that are extremely similar implies that in Haemophilus (as in most genera) the naming of species according to hosts is not likely to prove helpful. In our opinion names such as $H$. parahaemolyticus (39), $H$. parasuis, and $H$. paragallinarum (3) might therefore be best regarded as subjective synonyms of other names, in this instance, of $H$. parainfluenzae.

If three main centers of variation are accepted, corresponding to clusters 1,2 and 3, these would be regarded as subgenera in the light of current taxonomic views, and this may be the best course. Nevertheless, although we still lack good criteria for deciding on the categorical rank of clusters, by comparison with the taxonomy of other groups of bacteria these three clusters would be quite appropriately treated as species. They are formed at similarity levels that are quite usual for species in other genera of bacteria, indeed rather higher than the common level of 75 to $80 \%(32,54)$.

We know of no evidence to suggest that serological or genetic relationships between these clusters would be out of keeping with species status. As noted, fuller study may reveal subgroups representing $H$. haemoglobinophilus and some additional species. Strains of Haemophilus may be much more common in normal persons than is often thought (49), and new species may be found if looked for. If for the present the three clusters are treated as species, their correct names appear to be as follows: cluster 1, Haemophilus influenzae; cluster 2, Haemophilus parainfluenzae ; cluster 3, Haemophilus aphrophilus.

We studied too few strains of the Actinobacillus-Pasteurella group to obtain such information about the relationships of the species of this cluster. It is well known that Actinobacillus lignieresii and $A$. equuli are close species, and this has been recently discussed by Ross et al. (45). The findings on the Pasteurella strains 
studied are in fair keeping with previous numerical taxonomy on the genus $(52,60,62)$, and they confirmed the distinction between Pasteurella and Yersinia. The behavior of types $A$ and $\mathrm{T}$ of $P$. haemolytica Newsom and Cross in the different analyses adds to the growing evidence, reviewed by Shreeve, Ivanov, and Thompson (48), that these types may be less similar than generally thought and are possibly different species. The original strains of Newsom and Cross (38) were evidently type A according to criteria given by Shreeve et al., despite all of them being arabinose negative, so that if the types were separated into two species, type $\mathrm{T}$ would be the form requiring a new name.

At present the genera Actinobacillus, Haemophilus, and Pasteurella are included in the family Brucellaceae in Bergey's Manual (7). They are, however, phenetically very different from Brucella and similar genera, as we have shown elsewhere (22). They might, therefore, be segregated to form the nucleus of a new family, as they do not appear sufficiently similar to the Enterobacteriaceae, the other obvious possibility. Another genus that might also be associated with them is Eikenella, established by Jackson and Goodman (20) for the facultatively anaerobic organisms previously called Bacteroides corrodens, because although its $\mathrm{GC}$ ratio is a good deal higher, 57 to $58 \%$ $(18,20)$, it has a number of similarities with Haemophilus and Pasteurella as Jackson and Goodman point out. We have doubts about the authenticity of the only strain of Noguchia we studied (22), so the position of this genus must remain dubious at present.

\section{ACKNOWLEDGMENTS}

We thank M. J. Sackin for assistance with computing, and one of us (R. J.) acknowledges the receipt of a Scholarship from the Medical Research Council.

\section{REPRINT REQUESTS}

Address requests for reprints to: Prof. P. H. A. Sneath, Medical Research Council Microbial Systematics Unit, University of Leicester, University Road, Leicester, England.

\section{LITERATURE CITED}

1. Bergey, D. H., F. C. Harrison, R. S. Breed, B. W. Hammer, and F. M. Huntoon. 1923. Bergey's manual of determinative bacteriology, 1st ed. The Williams and Wilkins Co., Baltimore.

2. Biberstein, E. L., P. D. Mini, and M. G. Gills. 1963. Action of Haemophilus cultures on $\delta$ aminolevulinic acid. J. Bacteriol. 86:814-819.

3. Biberstein, E. L., and D. C. White. 1969. A proposal for the establishment of two new Haemophilus species. J. Med. Microbiol. 2:75-78.

4. Biberstein, E. L., and K. Zinnemann. 1971. Report (1966-1970) of the Subcommittee on the Taxonomy of Haemophilus to the International Committee of Nomenclature of Bacteria. Int. J. Syst. Bacteriol. 21:133-134.

5. Boyce, J. M. H., J. Frazer, and K. Zinnemann. 1969. The growth requirements of Haemophilus aphrophilus. J. Med. Microbiol. 2:55-62.

6. Breed, R. S., E. G. D. Murray, and A. P. Hitchins. 1948. Bergey's manual of determinative bacteriology, 6th ed. The Williams and Wilkins Co., Baltimore.

7. Breed, R. S., E. G. D. Murray, and N. R. Smith. 1957. Bergey's manual of determinative bacteriology, 7 th ed. The Williams and Wilkins Co., Baltimore.

8. Buchanan, R. E., J. G. Holt, and E. F. Lessel, Jr. 1966. Index Bergeyana. An annotated alphabetic listing of names of the taxa of the bacteria. The Williams and Wilkins Co., Baltimore.

9. de Blieck, L. 1931. Een haemoglobinophile bacterie als oorzaak van coryza infectiosa gallinarum. Tijdschr. Diergeneesk. 58:310-314.

10. Delaplane, J. P., L. E. Erwin, and H. O. Stuart. 1934. A hemophilic bacillus as the cause of an infectious rhinitis, p. 1-12. Agric. Exp. Sta. R.I. St. Coll. Bull. no. 244.

11. Delaplane, J. P., L. E. Erwin, and H. O. Stuart. 1938. The effect of the $\mathrm{X}$ factor, of sodium chloride, and of the composition of the nutrient media upon the growth of the fowl coryza bacillus, Hemophilus gallinarum. J. Agric. Res. 56:919-926.

12. Delaplane, J. P., and H. O. Stuart. 1941. A study of the $\mathrm{C}$ factor as a requirement for growth of Hemophilus gallinarum. J. Agric. Res. 63:29-30.

13. Dunkelberg, W. E., Jr., R. Skaggs, and D. S. Kellogg, Jr. 1970. A study and new description of Corynebacterium vaginale (Haemophilus vaginalis). Amer. J. Clin. Pathol. 53:370-377.

14. Frazer, J., K. Zinnemann, and J. M. H. Boyce. 1969. The effect of different environmental conditions on some characters of Haemophilus paraphrophilus. J. Med. Microbiol. 2:563-566.

15. Gardner, H. L., and C. D. Dukes. 1955. Haemophilus vaginalis vaginitis. A newly defined specific infection previously classified "nonspecific" vaginitis. Amer. J. Obstet. Gynecol. 69:962-976.

16. Gower, J. C. 1971. A general coefficient of similarity and some of its properties. Biometrics 27:857-871.

17. Hill, L. R. 1966. An index to deoxyribonucleic acid base compositions of bacterial species. J. Gen. Microbiol. 44:419-437.

18. Hill, L. R., J. J. S. Snell, and S. P. Lapage. 1970. Identification and characterisation of Bacteroides corrodens. J. Med. Microbiol, 3:483-491.

19. Hugh, R., and E. Leifson. 1953. The taxonomic significance of fermentative versus oxidative metabolism of carbohydrates by various gram negative bacteria. J. Bacteriol, 66:24-26.

20. Jackson, F. L., and Y. E. Goodman. 1972. 
Transfer of the facultatively anaerobic organism Bacteroides corrodens Eiken to a new genus, Eikenella. Int. J. Syst. Bacteriol. 22:73-77.

21. Janssen, W. A., and M. J. Surgalla. 1968. Morphology, physiology, and serology of a Pasteurella species pathogenic for white perch (Roccus americanus). J. Bacteriol. 96:1606-1610.

22. Johnson, R., and P. H. A. Sneath. 1973. Taxonomy of Bordetella and related organisms of the Families Achromobacteraceae, Brucellaceae, and Neisseriaceae. Int. J. Syst. Bacteriol. 23:381404.

23. Jones, D., and P. H. A. Sneath. 1970. Genetic transfer and bacterial taxonomy. Bacteriol. Rev. 34:40-81.

24. Judicial Commission. 1954. Opinion 13. Conservation and rejection of names of genera of bacteria proposed by Trevisan 1842-1890. Int. Bull. Bacteriol. Nomencl. Taxon 4:151-156.

25. Kennedy, P. C., E. L. Biberstein, J. A. Howarth, L. M. Frazier, and D. L. Dungworth. 1960. Infectious meningo-encephalitis in cattle, caused by a Haemophilus-like organism. Amer.' J. Vet. Res. 21:403-409.

26. Kennedy, P. C., L. M. Frazier, G. H. Theilen, and E. L. Biberstein. 1958. A septicaemic disease of lambs caused by Hemophilus agni (new species). Amer. J. Vet. Res. 19:645-654.

27. Khairat, O. 1940. Endocarditis due to a new species of Haemophilus. J. Pathol. Bacteriol. 50:497-505.

28. Kovacs, N. 1956. Identification of Pseudomonas pyocyanea by the oxidase reaction. Nature (London) 178:703.

29. Lehmann, K. B., and R. Neumann. 1896. Atlas und Grundriss der Bakteriologie und Lehrbuch der speciellen bakteriologischen Diagnostik, 2 vol. $1^{\mathbf{e}}$ Aufl. Teil 2. Lehmann, München.

30. Leidy, G., E. Hahn, and H. E. Alexander. 1956. On the specificity of the desoxyribonucleic acid which induces streptomycin resistance in Hemophilus. J. Exp. Med. 104:305-320.

31. Lewis, P. A., and R. E. Shope. 1931. Swine influenzae II. A hemophilic bacillus from the respiratory tract of infected swine. J. Exp. Med. 54:361-371.

32. Liston, J., W. Weibe, and R. R. Colwell, 1963. Quantitative approach to the study of bacterial species. J. Bacteriol. 85:1061-1070.

33. Mráz, O. 1969a. Vergleichende Studie der Arten Actinobacillus lignieresii und Pasteurella haemolytica. I. Actinobacillus lignieresii Brumpt 1910 ; emend. Zentralbl. Bakteriol. Parasitenk., Infektionskr. Abt. I Orig. 209:212-232.

34. Mráz, O. 1969b. Vergleichende Studie der Arten Actinobacillus lignieresii und Pasteurella haemo. lytica. II. Pasteurella haemolytica Newsom und Cross, 1932. Zentralbl. Bakteriol. Parasitenk., Infektionskr. Abt. I Orig. 209:336-349.

35. Mráz, O. 1969 c. Vergleichende Studie der Arten Actinobacillus lignieresii und Pasteurella haemolytica. III. Actinobacillus haemolyticus (Newsom und Cross, 1932) comb. nov. Zentralbl. Bakteriol.
Parasitenk., Infektionskr. Abt. 1 Orig. 209:349364.

36. National Collection of Type Cultures 1958. Catologue of species. Medical Research Council memorandum no. 35. Her Majesty's Stationery Office, London.

37. Nelson, J. B. 1933. Studies on an uncomplicated coryza of the domestic fowl. I. The isolation of a bacillus which produces a nasal discharge. J. Exp. Med. 58:289-295.

38. Newsom, I. E., and F. Cross. 1932. Some bipolar organisms found in pneumonia in sheep. J. Amer. Vet. Ass. 80:711-718.

39. Pittman, M. 1953. A classification of the hemolytic bacteria of the genus Haemophilus: Haemophilus haemolyticus Bergey et al. and Haemophilus parahaemolyticus nov. spec. J. Bacteriol. 65:750-751.

40. Pritchett, I. W., and E. G. Stillman. 1919. The occurrence of Bacillus influenzae in throats and saliva. J. Exp. Med. 29:259-266.

41. Reyn, A., A. Birch-Andersen, and S. P. Lapage. 1966. An electron microscope study of thin sections of Haemophilus vaginialis (Gardner and Dukes) and some possibly related species. Can. J. Microbiol. 12:1125-1136.

42. Rivers, T. M. 1922a. Bacterial nutrition. Growth of a hemophilic bacillus on media containing only an autoclave-stable substance as an accessory factor. Johns Hopkins Hosp. Bull. 33:149-151.

43. Rivers, T. M. 1922b. Influenza-like bacilli. Growth of influenza-like bacilli on media containing only an autoclave-labile substance as an accessory food factor. Johns Hopkins Hosp. Bull 33:429-431.

44. Rogul, M., J. J. Brendle, D. K. Haapala, and A. D. Alexander. 1970. Nucleic acid similarities among Pseudomonas pseudomallei, Pseudomonas multivorans and Actinobacillus mallei. J. Bacteriol. 101:827-835.

45. Ross, R. F., J. E. Hall, A. P. Orning, and S. E. Dale. 1972. Characterization of an Actinobacillus isolated from the sow vagina. Int. J. Syst. Bacteriol. 22:39-46.

46. Shigidi, M. A., and A. B. Hoerlein. 1970. Characterization of the Haemophilus-like organism of infectious thromboembolic meningoencephalitis of cattle. Amer. J. Vet. Res. 31:1017-1022.

47. Shope, R. E. 1963. Porcine contagious pleuropneumonia. I. Experimental transmission, etiology, and pathology. J. Exp. Med. 119:357-368.

48. Shreeve, B. J., I. N. Ivanov, and D. A. Thompson. 1970. Biochemical reactions of different serotypes of Pasteurella haemolytica. J. Med. Microbiol. 3:356-358

49. Sims, W. 1970. Oral haemophili. J. Med. Microbiol. 3:615-625.

50. Smith, G. R. 1959. Isolation of two types of Pasteurella haemolytica from sheep. Nature (London) 183:1132-1133.

51. Smith, G. R. 1961. The characteristics of two types of Pasteurella haemolytica associated with different pathological conditions in sheep. J. 
Pathol. Bacteriol. 81:431440.

52. Smith, J. E., and E. Thal. 1965. A taxonomic study of the genus Pasteurella using a numerical technique. Acta Pathol. Microbiol. Scand. 64:213-223.

53. Sneath, P. H. A. 1968. Vigour and pattern in taxonomy. J. Gen. Microbiol. 54:1-11.

54. Sneath, P. H. A. 1972. Computer taxonomy, p. 29-98. In J. R. Norris and D. W. Ribbons (ed.), Methods in Microbiology, vol. 7A. Academic Press Inc., London.

55. Sneath, P. H. A., and S. T. Cowan. 1958. An electro-taxonomic survey of bacteria. J. Gen. Microbiol. 19:551-565.

56. Sneath, P. H. A., and R. Johnson. 1972. The effect on numerical taxonomic similarities of errors in microbiological tests. J. Gen. Microbiol. 72:377-392.

57. Sneath, P. H. A., and V. B. D. Skerman. 1966. A list of type and reference strains of bacteria. Int. J. Syst. Bacteriol. 16:1-133.

58. Snieszko, S. F., P. J. Griffin, and S. B. Friddle. 1950. A new bacterium (Hemophilus piscium n. sp.) from ulcer disease of trout. J. Bacteriol. 59:699-710.

59. Sokal, R. R., and P. H. A. Sneath. 1963. Principles of numerical taxonomy. W. H. Freeman \& Co., San Francisco.

60. Stevens, M. 1969. Development and use of multi-inoculation test methods for a taxonomic study. J. Med. Lab. Technol. 26:253-263.
61. Stillman, E. G., and J. M. Bourn. 1920. Biological study of the hemophilic bacilli. J. Exp. Med. 32:665-682.

62. Talbot, J. M., and P. H. A. Sneath. 1960. A taxonomic study of Pasteurella septica especially of strains isolated from human sources. J. Gen. Microbiol. 22:303-311.

63. White, D. C., and S. Granwick. 1963. Hemin biosynthesis in Haemophilus. J. Bacteriol. $85: 842-850$

64. Winslow, C. E. A., J. Broadhurst, R. E. Buchanan, C. Krumwiede, Jr., L. A. Rogers, and G. H. Smith. 1917. The families and genera of the bacteria. Preliminary report of the Committee of the Society of American Bacteriologists on characterization and classification of bacterial types. J. Bacteriol. 2:505-566.

65. Zinnemann, K., K. B. Rogers, J. Frazer, and J. M. H. Boyce. 1968. A new V-dependent Haemophilus species preferring increased $\mathrm{CO}_{2}$ tension for growth and named Haemophilus paraphrophilus, nov. sp. J. Pathol. Bacteriol. 96:413-419.

66. Zinnemann, K., K. B. Rogers, J. Frazer, and S. K. Devaraj. 1971. A haemolytic V-dependent $\mathrm{CO}_{2}$ preferring Haemophilus species (Haemophilus paraphrohaemolyticus nov. spec.). J. Med. Microbiol. 4:139-143.

67. Zinnemann, K., and G. C. Turner. 1963. The taxonomic position of "Haemophilus vaginalis" [Corynebacterium vaginale]. J. Pathol. Bacteriol. 85:213-219. 